\title{
Bone marrow fibrosis (pseudo-myelofibrosis) in human kala-azar
}

\author{
Fibrose da medula óssea (pseudomielofibrose) \\ no calazar humano
}

\begin{abstract}
Francisco Dário Rocha Filho, Francisco Valdeci de Almeida Ferreira, Flávia de Oliveira Mendes, Fernanda Nogueira Holanda Ferreira, Alexandre Karbage, Marília Lage Alencar and Danielle Costa
\end{abstract}

\begin{abstract}
Thirty cases of human kala-azar were diagnosed by iliac crest biopsy and myeloculture. Histological analysis of 12 patients showed diffuse thickening of reticulin fibers. To the best of our knowledge, this is the third report describing secondary bone marrow fibrosis (myelofibrosis-like) associated with kala-azar. Patients with positive bone marrow fibrosis $(\mathbf{p b m f}=12)$ were compared to patients without detectable bone marrow fibrosis $(\mathbf{w b m f}=18)$. There were no significant differences in clinical and blood parameters following treatment. All patients showed regression of hepatosplenomegaly. Our findings suggest that associated bone marrow fibrosis is transient and did not interfere in the evolution of treated patients.
\end{abstract}

Key-words: Human kala-azar. Myelofibrosis. Bone marrow biopsy.

Resumo Trinta casos de pacientes com calazar foram diagnosticados mediante biópsia de crista ilíaca e mielo-cultura. Após estudo histológico 12 apresentavam espessamento difuso da rede de reticulina Pelo que foi possível resgatar na literatura, apenas dois relatos descrevem uma fibrose medular difusa (como mielofibrose) secundária ao calazar humano. Não foi encontrada diferença significativa nos parâmetros clínico-laboratoriais (hepatoesplenomegalia, hematócrito, hemograma, plaquetas e proteínas séricas), havendo tendência semelhante à regressão da hepato-esplenomegalia e melhora dos parâmetros laboratoriais nos dois grupos (com e sem fibrose medular difusa). Os dados permitem inferir que tal fibrose pode ser transitória não interferindo na evolução ou na resposta ao glucantime.

Palavras-chaves: Calazar humano. Fibrose da medula óssea. Mielofibrose.

The myelofibrosis can be idiopathic or seen in lymphoproliferative or myeloproliferative diseases, myelodysplasias, systemic mastocytosis, metastasis of epithelial malignant neoplasias, and in non-neoplastic diseases. Examples of the latter condition are tuberculosis, osteomalacia, Gaucher's disease, osteomyelytis, autoimmune diseases, congenital diseases, post radiotherapy and necrosis. Recently, a condensation in the reticulin fibers was described in AIDS patients 238141112 .
In the literature, the association of myelofibrosis with human kala-azar was reported in only three cases $^{613}$. However, the presence of partial or total fibrosis in other hematopoetic tissues, in cases of long-standing parasitism, had been previously described ${ }^{1} 1011$.

Since the State of Ceará has a high incidence of kala-azar, we initially searched for possible differences in terms of clinical manifestations, laboratory parameters, disease progression, and

Department of Pathology and Legal Medicine of the Faculty of Medicine. Federal University of Ceará, Fortaleza, Ceará State. Address to: Dr. Francisco Dário Rocha Filho. R. Nunes Valente 2220/1301, 60125-071 Fortaleza, CE, Brasil.

Tel: 5585 288-8305; fax: 5585 288-8316

e-mail:valdeci@ufc.br

Recebido para publicação em 27/10/98. 
response to treatment (Glucantime) of patients who presented with bone marrow fibrosis (pbmf = positive bone marrow fibrosis) associated with kala-azar to evaluate the frequency and the implications of bone marrow fibrosis in the outcome of human visceral leishmaniasis.

\section{MATERIAL AND METHODS}

Thirty patients ( 25 men and 5 women) of the Hematology and Haemotherapy Center of Fortaleza-Ceará (HEMOCE), whose diagnostic confirmation required bone marrow aspirate, biopsy and culture, were included into this study. The age spread was 5 to 63 years. The patients were divided in two groups: 12 with positive bone marrow fibrosis (pbmf) and 18 without bone marrow fibrosis (wbmf), according to the results of the analisys with silver stain.

Clinical and laboratory findings: clinical manifestations, physical findings, bone marrow analysis (aspirate, biopsy, and culture), peripheral blood parameters (automated counter H1-Bayer) and protein eletrophoresis were reviewed .

The fragments of the biopsy were fixed in $10 \%$ aqueous formaldehyde and paraffin- embedded and microtome sections $(5 \mu \mathrm{m})$ were stained with Hematoxilin-Eosin and with Gomori silver stain.

The clinical, epidemiologic and pertinent laboratory data were submitted to statistical analysis and to Student-Fisher test, with the degree of confidence set at or greater than $95 \%$ of probability degree $(p=0,05)$.

\section{RESULTS}

All the 30 patients, with positive parasitism detected by bone marrow culture, had paleness, hepatosplenomegaly, albumin/globulin inversion, low hematocrit and hemoglobin levels. There was one HIV positive patient (pbmf, case $\mathrm{nr}$ 2) and one with HCV positive (wbmf, case $\mathrm{nr} 5$ ). See Tables 1 and 2.
There was a clear male predominance $(5 / 1)$ in the economically active group, as was epidemiologically expected for cases of kala-azar.

There were no differences in response to therapy with glucantime between the two groups and all cases presented progressive clinical improvement, even those who were positive for HIV and for HCV.

Table 1 - Human kala-azar. Patients with (pbmf) and without bone marrow fibrosis (wbmf).Distribution by age and sex; progression of hepatosplenomegaly, before and after (in italic) treatment with glucantime (mean values).

\begin{tabular}{|c|c|c|c|c|c|}
\hline \multirow[t]{2}{*}{ Group } & \multirow[t]{2}{*}{ Age (years) } & \multicolumn{2}{|c|}{ Sex } & \multirow{2}{*}{$\begin{array}{c}\text { Spleen } \\
\mathrm{cm}\end{array}$} & \multirow{2}{*}{$\begin{array}{c}\text { Liver } \\
\mathrm{cm} \text { below right costal arch }\end{array}$} \\
\hline & & $\mathrm{M}$ & $\mathrm{F}$ & & \\
\hline pbmf (12) & $17-63(30)$ & 10 & 2 & $11.8(4.4)$ & $6.1(4.1)$ \\
\hline wbmf (18) & $5-53(26)$ & 15 & 3 & $8.2(7.8)$ & $4.8(4.2)$ \\
\hline $\mathrm{p}$ values & & & & 0.50 & 0.34 \\
\hline
\end{tabular}

Table 2 - Human kala-azar. Patients with (pbmf) and without bone marrow fibrosis (wbmf). Laboratory findings before and after (in italic) treatment with glucantime.

\begin{tabular}{lccccc}
\hline Group & $\begin{array}{c}\text { Hemoglobin } \\
\mathrm{g} / \mathrm{dL}\end{array}$ & $\begin{array}{c}\text { Leukocytes } \\
\times 10^{9} \mathrm{~L}\end{array}$ & $\begin{array}{c}\text { Platelets } \\
\times 10^{9} \mathrm{~L}\end{array}$ & $\begin{array}{c}\text { Albumin } \\
\mathrm{g} / \mathrm{dl}\end{array}$ & \multicolumn{2}{c}{ Globulins } \\
& $8.3(10.2)$ & $2.42(4.13)$ & $122.4(163)$ & $2.8(3.9)$ & $5.3(4.0)$ \\
\hline $\mathrm{pbmf}=12$ & $7.9(9.9)$ & $2.68(4.41)$ & $107.7(178.7)$ & $2.9(3.2)$ & $5.2(5.0)$ \\
wbmf $=18$ & 0.2 & 0.89 & 0.06 & 0.49 & 0.16 \\
$\mathrm{p}$ values & & & & & \\
\hline
\end{tabular}

The histopathologic analysis showed, in all cases, a tendency to hypercellularity, plasmocytosis, interstitial lymphocytosis, frequent presence of dysplastic megakaryocytes, increased polimorphonuclear volume and, eventually, erythrophagocytosis. The parasitism was constant, although variable. Eleven cases showed moderately thickened, and one with more intensely thickened reticulin network (Figures 1 and 2). 


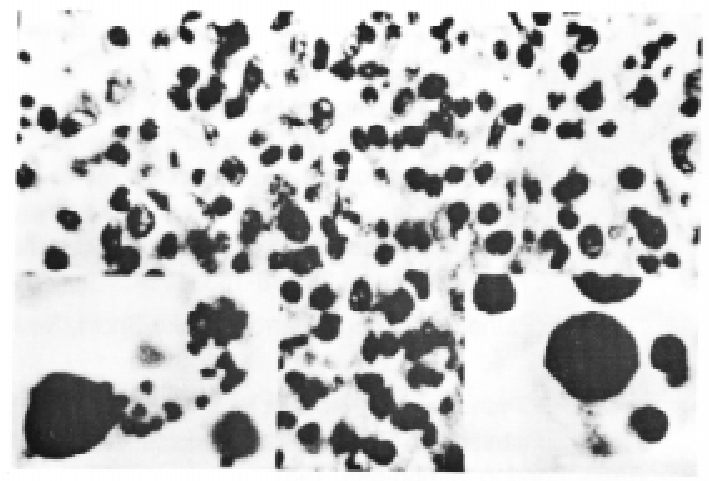

Figure 1 - Bone Marrow Biopsy. HE 40x. Hypercelularity: plasmocytosis, lymphocytosis, monocytosis, infested macrophages. Insets: Bone Marrow Aspirate: MayGrünwald-Giemsa. 100x. Parasitism. B) Erythrophagocytosis.

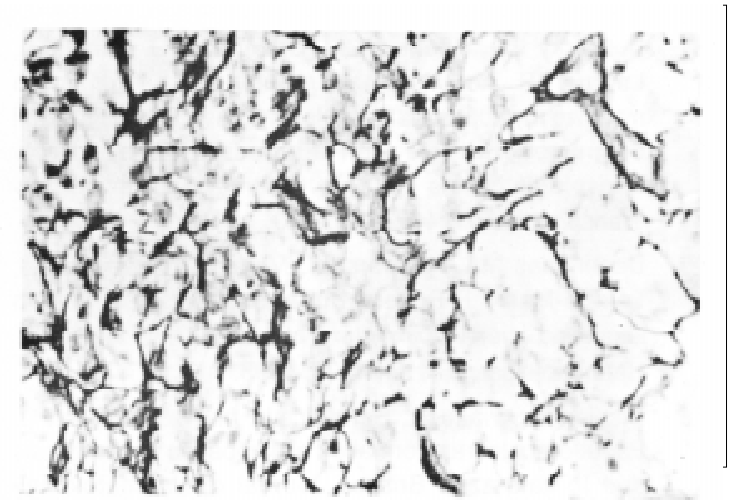

Figure 2 - Bone Marrow Biopsy. Silver stain. 40X. Bone marrow fibrosis.

\section{DISCUSSION}

Secondary bone marrow fibrosis is frequentelly described in a wide range of illnesses ${ }^{231014}$. Its association with kala-azar had been reported in only three cases $^{6}{ }^{13}$. Deposition of fibrous matrix is increased by the proliferation and stimulation of the marrow fibroblast ${ }^{8}{ }^{13}$, with various interstitial and basement membrane glycoprotein, including collagen types I, III, IV, V, VI, fibronectin, vitronectin,laminin and tenascin ${ }^{11}$.

It is believed that the pro-megakaryoblasts secretors of TGF-B (transforming growth factor $B)$ have a role in the pathogenesis of myelofibrosis, especially in the myeloproliferative diseases, by stimulating the fibroblasts and collagen production ${ }^{69}$. In addition to this, the deposition of immune complexes, fibroblast- stimulating factor (by activated macrophages), and the increased production of PDGF (platelet derived growth factor) and pf-4 (platelet factor 4) by megakaryocytes ${ }^{6}{ }^{1213}$, are also considered important in the pathogenesis of myelofibrosis and others megacariocyte/ platelet derived growth factors. According to Saleem et $\mathrm{al}^{13}$, more then one of the cited mechanisms are involved. However there is a need for establishing experimental models to confirm the pathogenic mechanisms of myelofibrosis in human kala-azar.

In our cases there were no differences in response to therapy with glucantime between the two groups, all cases presented progressive clinical improvement, even those who were positive for HIV and for HCV (Tables 1 and 2). We believe that the bone marrow fibrosis seen in our twelve cases had no significant influence in the progression of the disease, nor in response to treatment (glucantime).

We provisionally accept the hypothesis of the non-progressive,or even regressive, tendency of the bmf in kala-azar, based on the data obtained in the literature about reversal of bone marrow fibrosis after corticosteroid ${ }^{7}$ or alfa-interferon therapy ${ }^{5}$ and bone marrow transplantation ${ }^{4}$. However, there is a need for creating an experimental model and proceed with histochemical analysis to determine the nature of the filaments formed in the bone marrow fibrosis in kala-azar.

Both groups (pbmf and wbmf) were similar regarding age, with mean, median and mode superimposed, with predominance of the young adults and men, according to the known epidemiologic pattern of human kala-azar.

There were no significant statistical differences between the two groups, in any of the patterns studied, except for sex, nor in the progression of the disease after treatment. Thus, the bone marrow fibrosis observed in our cases was probably transitory.

\section{REFERENCES}

1. Andrade Z. Aspectos morfológicos da disproteinemia no Calazar. Revista da Associação Médica Brasileira 5:413420, 1956.

2. Brain BJ, Wickramasinghe SN. Pathology of the bone marrow: general considerations In: Wickramasinghe
SN (ed) Blood and Bone Marrow. Churchill Livingstone, New York, p.73-105, 1986.

3. Brunning RD. Bone Marrow. In: Rosai J (ed) Ackerman's surgical pathology, $8^{\text {th }}$ edition, Mosby, St. Louis, p 17971915, 1996. 
4. Bullorsky EO, Shanley CM, Stemmelin G, Venditti J, Lajous JR. Acute megakaryoblastic leukemia with massive myelofibrosis: complete regression and reversal of marrow fibrosis with allogeneic bone marrow transplantation as the only treatment. Bone Marrow Transplantation 6:449-452, 1990.

5. Domingues MA, Haepers AT, Massaut IH, Vassalo J, Lorand-Metze I. Reversal of bone marrow fibrosis in idiopathic myelofibrosis after teatment with alfa-interferon. Haematologica 83:1124-1125, 1998.

6. Disdier P, Swiader L, Serratrice J, Mary C, Weiller PJ. Pseudo-acute transformation an idiopathic myelofibrosis due to kala-azar. Bristish Journal of Haematolology 100:449, 1998.

7. Inoue Y, Matsubara A, Okuya S, Okafuji K, Kaku $\mathrm{K}$, Kaneko T. Myelofibrosis and systemic lupus erythematosus: reversal of fibrosis with high-dose corticosteroid therapy. Acta Haematologica 88:32-36, 1992.

8. Martyré MC, Ramquin N, Le Bousse - Kerdiler MC, Heivillard S, Benyahia B, Dupirez B, Demonry J, Bauters F. Transforming growth factor $B$ and megakariocytes in the pathogenesis of idiopathic myelofibrosis. British Journal of Haematology 88:9-16, 1994.

9. Massauzi N, Tanaka J, Ohizumi H, Kiyama Y, Naohara T, Higa T, Kasai M, Imamura M, Miyazaki T. Reversal of myelofibrosis is na important pre-transplant factor for bone marrow graftting- a successful case of allogeneic bone marrow transplantation for an acute megakayoblastic leukemia. Rinsho Ketsueki 35:148-153, 1994.

10. Naeim F. Pathology of bone Marrow. Igaku-Shoin, New York, 1992.

11. Ridley DS. Pathology. In:Peters W, Killick-Kendric R (eds) The leishmaniasis in Biology and Medicine. Academic Press, London, p. 666-695, 1987.

12. Reilly JT. Idiopathic myelofibrosis:pathogenesis, natural history and management. Blood Review 11:233-242, 1997.

13. Saleem M, Anwar M, Khan Ah, Nasseem L, Ahmad M. Myelofibrosis in visceral leishmaniasis. British Journal of Haematolology 78:573-4, 1991.

14. Sultan CL, Scoazec JY, Imbert M. Histopathologie de la Moelle Osseuse. Masson, Paris, p. 166, 1991. 